\title{
Role of X-Ray Crystallography in Structural Studies of Pyridyl-Ruthenium Complexes
}

\author{
Dai Oyama \\ Fukushima University \\ Japan
}

\section{Introduction}

It is extremely important for chemists to establish the structure of new compounds. A more accurate understanding of the structure leads to the construction of appropriate reaction systems. For example, although the well-known platinum complex, $\left[\mathrm{PtCl}_{2}\left(\mathrm{NH}_{3}\right)_{2}\right]$, has two geometrical isomers (cis and trans in Fig. 1), only the cis-isomer (so-called cisplatin) exhibits prominent antitumor activity (Reedijk, 1996; Rosenberg et al., 1969).
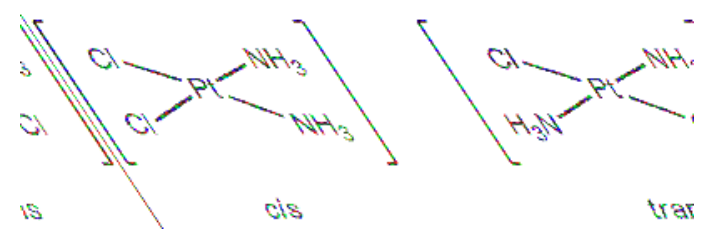

Fig. 1. Two geometrical isomers in $\left[\mathrm{PtCl}_{2}\left(\mathrm{NH}_{3}\right)_{2}\right]$.

Characterization of most structures of simple organic compounds is usually carried out by various spectroscopic measurements including NMR, IR and MS. On the other hand, detailed structural characterization of coordination compounds is achieved by X-ray diffraction methods, which can provide not only information on the geometrical structures, but also full bond parameters. In particular, single crystal X-ray diffraction is the most powerful tool for the detailed structural analysis of crystalline coordination compounds.

The aim of this chapter is to demonstrate particular advantages of X-ray structural analysis when compared with other techniques on coordination compounds. Herein, X-ray analysis of a variety of mononuclear ruthenium complexes containing pyridyl substituents is mainly described.

\section{Coordination geometries and coordination modes}

Some isomeric pairs of $[\mathrm{Ru}(\mathrm{tpy})(\mathrm{L}) \mathrm{Cl}]^{n+}$ type complexes (tpy $=2,2^{\prime}: 6^{\prime}, 2^{\prime \prime}$-terpyridine, $\mathrm{L}=$ asymmetrical pyridyl-based bidentate ligands in Fig. 2) have been prepared and structurally characterized as precatalysts to investigate the effect of isomeric structural features on the catalytic epoxidation process (Chowdhury et al., 2011; Dakkach et al., 2010). In the complex $\left[\mathrm{Ru}(\mathrm{tpy})(1)\left(\mathrm{OH}_{2}\right)\right]^{2+}$, the distal isomer exhibits better activity because it contains a pyridine 
$\mathrm{C}-\mathrm{H}$ bond nearly parallel to the $\mathrm{Ru}-\mathrm{O}$ bond, whereas for the proximal isomer this position is occupied by a $\mathrm{C}-\mathrm{CH}_{3}$ group and thus exerts a much stronger steric effect (Dakkach et al., 2010). In the complex $\left[\mathrm{Ru}(\mathrm{tpy})(2)\left(\mathrm{OH}_{2}\right)\right]^{+}$, on the other hand, the proximal isomer has been established to be an excellent catalyst for the chemoselective epoxidation though limited differences in electronic structural features exist between the isomeric pair (Chowdhury et al., 2011). These examples indicate that it is important to clearly distinguish the molecular structures of the compounds. In this section, representative examples of ruthenium complexes which possess asymmetrical multidentate ligands or multiple donor atoms are surveyed.
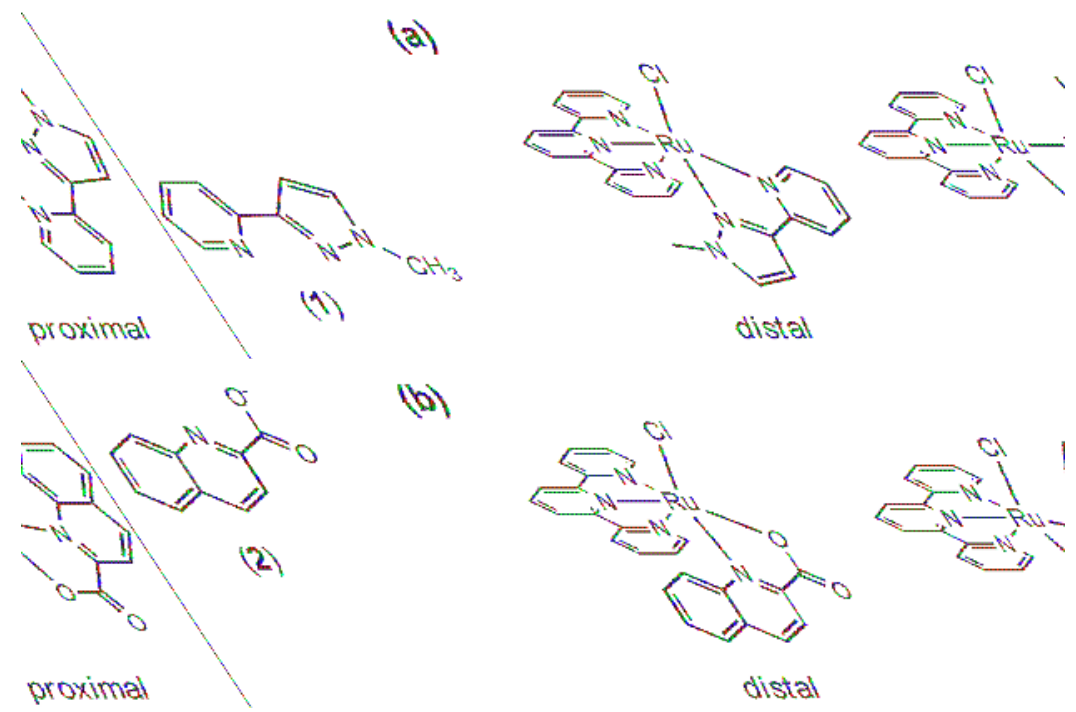

Fig. 2. Asymmetrical pyridyl-based ligands (1 and 2$)$ and their ruthenium complexes. (a): $[\mathrm{Ru}(\mathrm{tpy})(1) \mathrm{Cl}]^{+},(\mathrm{b}):[\mathrm{Ru}(\mathrm{tpy})(2) \mathrm{Cl}]$.

\subsection{Coordination geometries of azopyridyl complexes}

2-Azopyridyl derivatives (Fig. 3) behave as mono-, bi- and tridentate ligands, thus a wide variety of mononuclear complexes can be prepared. For example, 2-phenylazopyridine (3), which represents the most fundamental azopyridyl compound, is a bidentate ligand that can coordinate to a metal ion through the lone pairs on the pyridine and the azo nitrogen atoms, thereby forming a stable chelating 5 -membered ring.

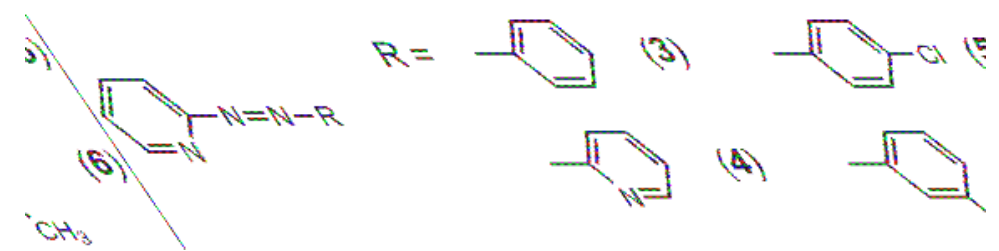

Fig. 3. Bidentate 2-azopyridyl ligands described herein. 
Since the bidentate ligand (3) lacks a two-fold symmetry axis, there are five possible isomers in $\left[\mathrm{Ru}(3)_{2} \mathrm{Cl}_{2}\right]$ (Fig. 4) (Bao, K. Krause \& R. A. Krause, 1988; Goswami, Chakravarty \& Chakravorty, 1981; R. A. Krause \& K. Krause, 1982 \& 1980; Velders et al., 2004). Among them, $\alpha, \beta$ and $\varepsilon$ adopt the cis-geometry with respect to the two chlorido ligands, whereas $\gamma$ and $\delta$ are the trans-geometry. Besides the $\varepsilon$ isomer, the structures have been determined by X-ray crystallography: the molecular structures of two $\left[\mathrm{Ru}(3)_{2} \mathrm{Cl}_{2}\right]$ isomers $(\alpha$ - and $\beta$ isomers) were published in 1984 (Seal \& Ray, 1984), the third $(\gamma)$ and the fourth $(\delta)$ isomers were reported in 2000 and 2004, respectively (Velders et al., 2004 \& 2000).

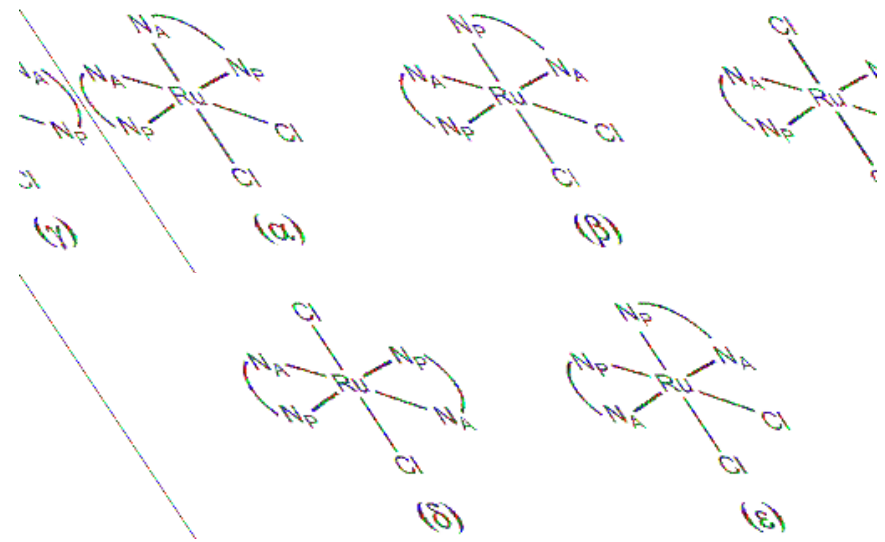

Fig. 4. Chemical structures of the five stereoisomers of $\left[\mathrm{Ru}(3)_{2} \mathrm{Cl}_{2}\right] . \mathrm{N}_{\mathrm{A}}$ and $\mathrm{N}_{\mathrm{P}}$ represent the azo and pyridine nitrogen atoms, respectively.

Ruthenium(II) complexes containing both $\mathrm{Ru}-\mathrm{C}$ bonds and 3 as supporting ligands were synthesized by substituting chlorido ligand(s) in $\left[\mathrm{Ru}(3)_{2} \mathrm{Cl}_{2}\right]$ with $\mathrm{CO}$ or $\mathrm{CN}^{-}$(Oyama, Takatsuki \& Fujita, 2010). The molecular structure of $\left[\mathrm{Ru}(3)_{2}(\mathrm{CO}) \mathrm{Cl}\right]^{+}$determined by X-ray crystallography is shown in Fig. 5(a). The geometry of the complex corresponds to the $\alpha-$ isomer shown in Fig. 4. The carbonyl $\mathrm{C}-\mathrm{O}$ and $\mathrm{Ru}-\mathrm{Cl}$ bond distances, and the $\mathrm{Ru}-\mathrm{C}-\mathrm{O}$ bond angle are consistent with those observed for closely related complexes ( $\left[\mathrm{RuL}_{2}(\mathrm{CO}) \mathrm{Cl}\right]^{+}: \mathrm{L}=$ bidentate pyridine-based ligands), whereas the $\mathrm{Ru}-\mathrm{C}$ bond distance is longer than those in similar complexes (Clear et al., 1980; Kepert et al., 2004). This is because of the presence of two 3 ligands with azo moieties. In general, the Ru-N(azo) bond distances are shorter than those of the $\mathrm{Ru}-\mathrm{N}$ (pyridine) bonds in 3 in the ruthenium complexes (Velders et al., 2004). However, one of the $\mathrm{Ru}-\mathrm{N}(\mathrm{azo})$ bonds is very long; even longer than the distances of the $\mathrm{Ru}-\mathrm{N}$ (pyridine) bonds. This is caused by the trans influence of the CO ligand.

The crystal structure of $\left[\mathrm{Ru}(3)_{2}(\mathrm{CN})_{2}\right]$ is shown in Fig. $5(\mathrm{~b})$. Unexpectedly, the two CN groups are trans to each other, and the $\delta$-form (shown in Fig. 4) is observed. A $\delta$ arrangement is very rare, and was only recently reported for $\delta$ - $\left[\mathrm{Ru}(3)_{2} \mathrm{Cl}_{2}\right]$ (Velders et al., 2004). In the $\delta$-isomer, the two azo bonds (in mutual trans positions) should compete with each other for the $\mathrm{Ru}(\mathrm{II}) 4 \mathrm{~d}$ electron density, resulting in relatively long $\mathrm{Ru}-\mathrm{N}$ (azo) bonds in $\left[\mathrm{Ru}(3)_{2}(\mathrm{CN})_{2}\right]$ with respect to the equivalent bonds in $\gamma-\left[\mathrm{Ru}(3)_{2} \mathrm{Cl}_{2}\right]$ (Velders et al., 2004). This confirms that the $\mathrm{Ru}-\mathrm{N}(\mathrm{azo})$ bond order decreases in $\left[\mathrm{Ru}(3)_{2}(\mathrm{CN})_{2}\right]$. 
(a)

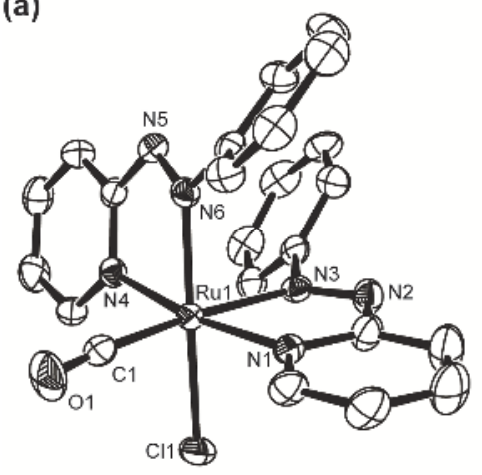

(b)

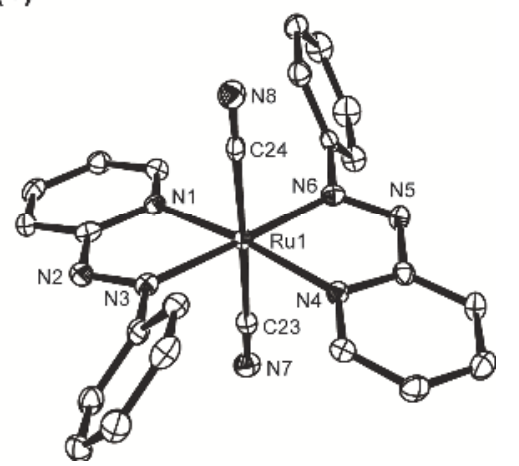

Fig. 5. Molecular structures of (a): $\left[\mathrm{Ru}(3)_{2}(\mathrm{CO}) \mathrm{Cl}\right]^{+},(\mathrm{b}):\left[\mathrm{Ru}(3)_{2}(\mathrm{CN})_{2}\right]$.

Although only the cis-isomer of $\left[\mathrm{Ru}(3)_{2}(\mathrm{CO}) \mathrm{Cl}\right]^{+}$is formed, the trans-isomer of $\left[\mathrm{Ru}(3)_{2}(\mathrm{CN})_{2}\right]$ formed preferentially despite the use of a cis- $\left[\mathrm{Ru}(3)_{2} \mathrm{Cl}_{2}\right]$ precursor. In $\left[\mathrm{RuL}_{2}(\mathrm{CN})_{2}\right](\mathrm{L}=$ bidentate pyridine-based ligands) complexes, the cis form is the preferred geometry for $2,2^{\prime}$ bipyridine and its analogues (Abe, Suzuki \& Shinozaki, 2010; Cheng, Cheung \& Che, 1997; Chow et al., 2005; Zhou et al., 2009), whereas the trans geometry is more stable in $\left[\mathrm{Ru}(3)_{2}(\mathrm{CN})_{2}\right]$.

Many analogous bis-azopyridine complexes, $\left[\mathrm{Ru}\left(\text { azopyridine }{ }_{2} \mathrm{~L}_{2}\right]^{n+}\right.$, have also been reported (Das et al., 2009; Hotze et al., 2000 \& 2005; Samanta et al., 2001; Shivakumar et al., 2000). In these complexes, the $\left[\mathrm{Ru}(4)_{2}(\mathrm{CO})\left(\mathrm{PPh}_{3}\right)\right]^{+/ 0}$ complexes form the unique $\varepsilon$-isomer examples.

In analogy with the bis-azopyridine complexes, the geometry of the complexes should also be consistent for the mono-azopyridine complexes because of the asymmetrical units of the azopyridines. For example, ruthenium complexes containing the ligand 3 and its analogue 5 ([Ru(azopyridine) $\left.\left.(\mathrm{H})(\mathrm{CO})\left(\mathrm{PPh}_{3}\right)_{2}\right]\right)$ exhibit two different geometries (Fig. 6) (Shivakumar et al., 2000). Therefore, it is important to control the orientation of the azopyridine ligands in preparing complexes that rely on the steric and/or electronic nature of the ligands. Such examples have been demonstrated in $[\mathrm{Ru}(3)(\mathrm{bpy}) \mathrm{Cl}(\mathrm{L})]^{+}$(bpy $=2,2^{\prime}$-bipyridine, $\mathrm{L}=\mathrm{CO}$ or $\mathrm{CH}_{3} \mathrm{CN}$ ) complexes. Here, the configuration of the incoming azopyridine ligand 3 can be regulated by the strength of the $\pi$-bonding ability of the co-ligands $L$ situated in the trans position: the pyridine nitrogen (weaker $\pi$-bonding character) of the incoming ligand 3 is selectively situated trans to the L ligand when L is a carbonyl, whereas the azo nitrogen (stronger $\pi$-bonding character) is situated trans to the acetonitrile ligand. Thus, the combination of $\mathrm{CO}$-pyridine nitrogen (strong-weak $\pi$-bonding character) and $\mathrm{CH}_{3} \mathrm{CN}$-azo nitrogen (weak-strong $\pi$-bonding character) are quite reasonable (Oyama, Asuma \& Takase, 2008). The molecular structures of $[\mathrm{Ru}(3)(\mathrm{bpy}) \mathrm{Cl}(\mathrm{L})]^{+}\left(\mathrm{L}=\mathrm{CO}\right.$ or $\left.\mathrm{CH}_{3} \mathrm{CN}\right)$ are shown in Fig. 7. The azo group of 3 in $[\mathrm{Ru}(3)(\mathrm{bpy}) \mathrm{Cl}(\mathrm{L})]^{+}$is clearly situated cis $(\mathrm{L}=\mathrm{CO})$ and trans $(\mathrm{L}=$ $\left.\mathrm{CH}_{3} \mathrm{CN}\right)$ to the $\mathrm{L}$ ligand. The corresponding complex with $4\left([\mathrm{Ru}(4)(\mathrm{bpy})(\mathrm{CO}) \mathrm{Cl}]^{+}\right)$is also selectively synthesized by using the above methodology (Oyama et al., 2009).

Molecular structures of various ruthenium mono-terpyridine complexes of the type $\left[\mathrm{Ru}(\text { tpy)(azopyridine) } \mathrm{L}]^{n+}\right.$ (azopyridine $=3,4,6 ; \mathrm{L}=\mathrm{Cl}, \mathrm{OH}_{2}, \mathrm{CH}_{3} \mathrm{CN}, \mathrm{NO}_{2}$ ) have been determined by X-ray analysis (Corral et al., 2006; Mondal, Walawalkar \& Lahili, 2000; Mondal et al., 2001; Ooyama \& Asaha, 2005; Oyama, Fujita \& Yui, 2008). The asymmetrical 
nature of azopyridines lead to the possibility of two isomers as shown in Fig. 8; however, only one isomer ( $\mathrm{a}$ in Fig. 8) has been characterized in all complexes.

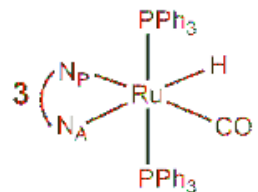

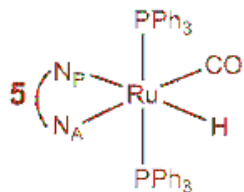

Fig. 6. Two different geometries in trans $\left(\mathrm{PPh}_{3}\right)-\left[\mathrm{Ru}(\right.$ azopyridine $\left.)(\mathrm{H})(\mathrm{CO})\left(\mathrm{PPh}_{3}\right)_{2}\right]$ (azopyridine $=(3)$ or $(5)$ ).

(a)

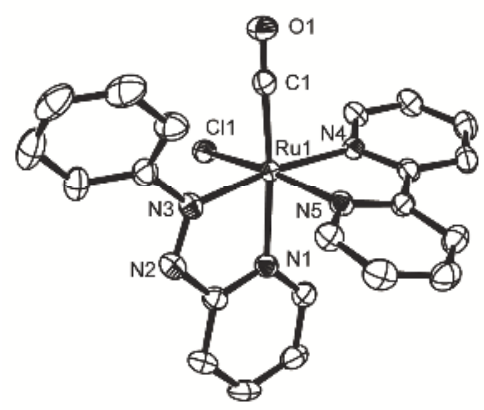

(b)

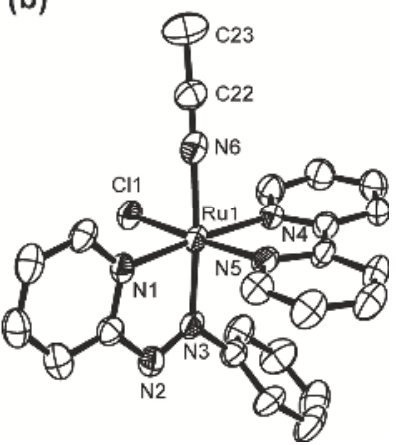

Fig. 7. Molecular structures of (a): $[\mathrm{Ru}(3)(\mathrm{bpy})(\mathrm{CO}) \mathrm{Cl}]^{+},(\mathrm{b}):\left[\mathrm{Ru}(3)(\mathrm{bpy})\left(\mathrm{CH}_{3} \mathrm{CN}\right) \mathrm{Cl}\right]^{+}$.
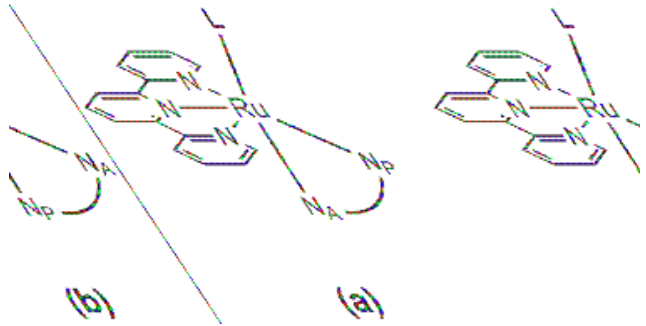

Fig. 8. Possible isomers in $[\mathrm{Ru}(\mathrm{tpy}) \text { (azopyridine)L }]^{n+}$ type complexes.

Finally, tris-bidentate and bis-tridentate azopyridine complexes are presented. The compound $\left[\mathrm{Ru}(\text { azopyridine })_{3}\right]^{n+}$ theoretically exists in two different isomeric forms (disregarding $\Delta, \Lambda$ enantiomerism), i.e., the meridional (mer) and facial (fac) isomers (Fig. 9). Only mer-[Ru(azopyridine $\left.)_{3}\right]^{2+}$ were obtained and crystallographically characterized due to the facial isomer of $\left.[\mathrm{Ru} \text { (azopyridine) })_{3}\right]^{2+}$ being sterically unfavorable because of the crowding of the three phenyl groups (Das et al., 2003; Hotze et al., 2005). Ruthenium complexes with tridentate azopyridine ligands in Fig. 10 have been reported (Samanta et al., 2008). The configuration is bis-meridional, and the relative orientations of the pairs of coordinated atoms are cis (pyridyl-N), trans (azo-N) and cis (arylanilido-N), respectively. 


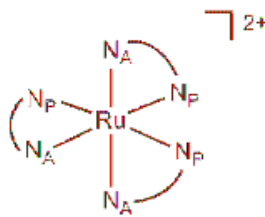

(mer)

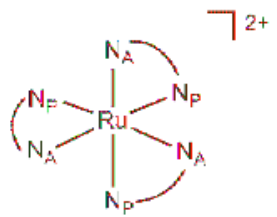

(fac)

Fig. 9. Possible isomers in $\left[\mathrm{Ru}(\text { azopyridine })_{3}\right]^{n+}$ type complexes.

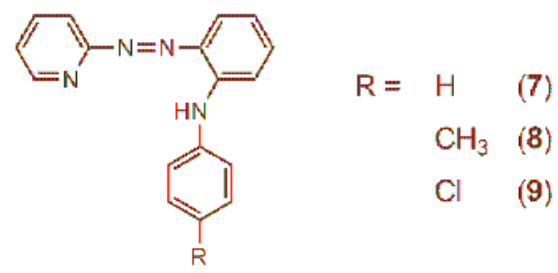

Fig. 10. Tridentate 2-azopyridyl ligands described herein.

\subsection{Coordination geometries of other pyridyl-based complexes}

The naphthyridines consist of a group of diazanaphthalenes with one nitrogen in each ring. In particular, the bidentate naphthyridine, 2-(2-pyridyl)-1,8-naphthyridine (pynp; 10 ), is a useful ligand for mononuclear systems (Fig. 11). For complexes with ligand 10; however, there is a stereochemical question with regard to the binding of ligand 10 because it has an asymmetrical structure. Consequently, it would be very interesting to study complexes involving 10 in an effort to understand the relationship between the coordination geometries of these complexes and their reactivities.<smiles>c1ccc(-c2ccc3cccnc3n2)nc1</smiles><smiles></smiles>

(10)

Fig. 11. Chemical structure of 2-(2-pyridyl)-1,8-naphthyridine (pynp) and its coordination to a metal center.

The $[\mathrm{Ru}(\mathrm{tpy})(10) \mathrm{Cl}]^{+}$complex acts as a catalyst for water oxidation: it shows excellent catalytic activity with turnover numbers (TNs) of 1,170 (Tseng et al., 2008). This value is the highest in the analogous $[\mathrm{Ru}(\mathrm{tpy})(\mathrm{L}) \mathrm{Cl}]^{+}$type complexes $(\mathrm{L}=$ bidentate polypyridyl ligands) whose TNs are in the range of 0-570. The ligand 10 differs from all of the other bidentate (L) because it is asymmetric. Although there are two possible isomers in $[\mathrm{Ru}(\mathrm{tpy})(10) \mathrm{Cl}]^{+}(\mathrm{Fig}$. 12), only one isomer (Fig. 12(b)) is isolated and its structure has been determined by X-ray crystallography (Tseng et al., 2008). Two isomeric mixtures of $[\mathrm{Ru}(\mathrm{tpy})(10) \mathrm{Cl}]^{+}$exist in solution (approximately 1:1), both of which can be separated by column chromatography. Alternatively, irradiation of visible light to isomeric mixtures of $[\mathrm{Ru}(\mathrm{tpy})(10) \mathrm{L}]^{2+}\left(\mathrm{L}=\mathrm{OH}_{2}\right.$ or $\mathrm{CH}_{3} \mathrm{CN}$ ) leads the formation of only one isomer in particular organic solvents (Oyama, 
Yuzuriya \& Takase, 2011). The resulting complex $\left(\left[\mathrm{Ru}(\mathrm{tpy})(10)\left(\mathrm{OH}_{2}\right)\right]^{2+}\right)$ is the proximal configuration (Fig. 12(a)), which differs from the corresponding chlorido complex.

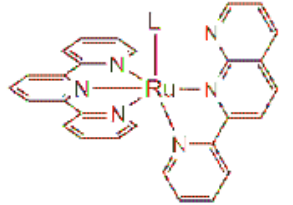

(a)

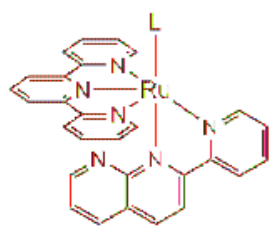

(b)

Fig. 12. Possible isomers in $[\mathrm{Ru}(\mathrm{tpy})(10) \mathrm{L}]^{n+}$ type complexes.

In contrast, particular stereoisomers could be selectively prepared in the cis$\left[\mathrm{Ru}(\text { bpy) }(10)(\mathrm{CO}) \mathrm{Cl}]^{+}\right.$system (Oyama, Hamada \& Takase, 2011). As shown in Fig. 13, although there are four possible geometries in the complex, only two types of the complex could be selectively synthesized. Although the prepared complexes are all single species as determined from the spectroscopic measurements, their structures cannot be assigned because of their spectral resemblance. Consequently, X-ray analysis was required to determine their detailed structures. The molecular structures of two $[\mathrm{Ru}(\mathrm{bpy})(10)(\mathrm{CO}) \mathrm{Cl}]^{+}$ isomers are shown in Fig. 14. One isomer corresponds to (a) in Fig. 13 (the pyridyl ring of 10 is situated trans to the CO ligand), the another isomer corresponds to (b) in Fig. 13 (the pyridyl ring of 10 is situated cis to the CO ligand).
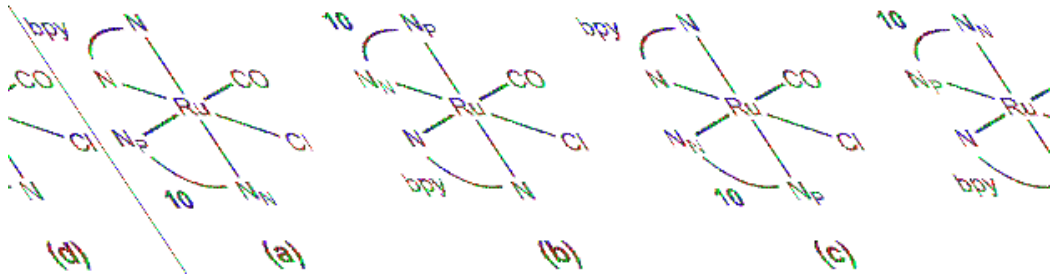

Fig. 13. Chemical structures of four stereoisomers in cis- $[\mathrm{Ru}(\mathrm{bpy})(10)(\mathrm{CO}) \mathrm{Cl}]^{+} . \mathrm{N}_{\mathrm{N}}$ and $\mathrm{N}_{\mathrm{P}}$ denote the naphthyridine nitrogen and the pyridine nitrogen, respectively.

(a)

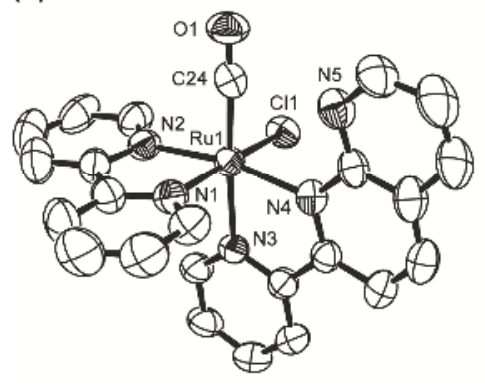

(b)

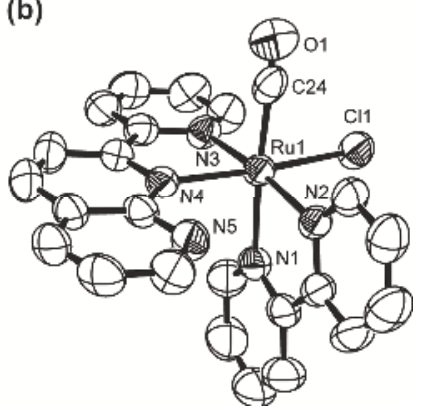

Fig. 14. Molecular structures of $[\mathrm{Ru}(\mathrm{bpy})(10)(\mathrm{CO}) \mathrm{Cl}]^{+}$. (a): isomer "a" in Fig. 13, (b): isomer "b" in Fig. 13. 
Picolinato (pic; 11) can also coordinate to a metal ion as an asymmetrical bidentate ligand (Fig. 15). The mono-pic complex, $\left[\mathrm{Ru}(11)(\mathrm{CO})_{2} \mathrm{Cl}_{2}\right]^{-}$, has been prepared and fully characterized, including X-ray analysis (Ooyama et al., 2003). Although three geometrical isomers are expected for $\left[\mathrm{Ru}(11)(\mathrm{CO})_{2} \mathrm{Cl}_{2}\right]^{-}$(Fig. 16(a)), only form (i) in Fig. 16(a) was confirmed, and neither form (ii) nor (iii) was detected in the solid state and in solutions. The asymmetrical chelate of 11 gives substantially different effects to the two Ru-CO bonds of $\left[\mathrm{Ru}(11)(\mathrm{CO})_{2} \mathrm{Cl}_{2}\right]^{-}$. The $\mathrm{Ru}-\mathrm{C}$ bond distance trans to the oxygen atom is shorter than another $\mathrm{Ru}-\mathrm{C}$ bond trans to the nitrogen atom (Fig. 17(a)). The complex containing mono-11, cis$\left[\mathrm{Ru}(\mathrm{bpy})(11)(\mathrm{CO})_{2}\right]^{+}$was also prepared by the reaction of $\mathrm{Hpic}$ with $\left[\mathrm{Ru}(\mathrm{bpy})(\mathrm{CO})_{2} \mathrm{Cl}_{2}\right]$, and only the type (iv) of the two possible isomers (iv) and (v) was obtained (Fig. 16(b) and Fig. 17(b)) (Ooyama et al., 2003).<smiles>O=C([O-])c1ccccn1</smiles>

(11)

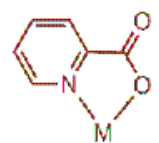

$\mathrm{M}$

Fig. 15. Chemical structure of picolinato (pic) and its coordination to a metal center.

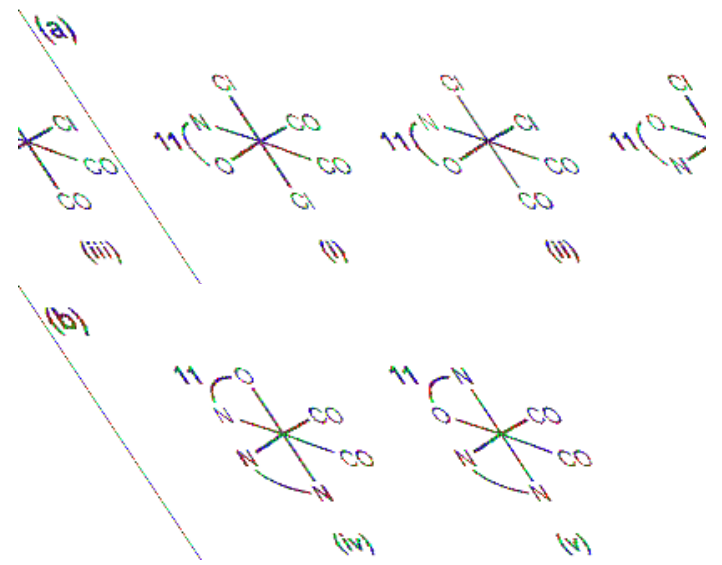

Fig. 16. Possible geometrical isomers containing 11. (a): [ $\left.\mathrm{Ru}(11)(\mathrm{CO})_{2} \mathrm{Cl}_{2}\right]^{-}$, (b): cis$\left[\mathrm{Ru}(\mathrm{bpy})(11)(\mathrm{CO})_{2}\right]^{+}$.

Two geometrical isomers (Fig. 18) of $[\mathrm{Ru}(\mathrm{tpy})(\mathrm{bpyO})(\mathrm{CO})]^{+}\left(\mathrm{bpyO}=2,2^{\prime}\right.$-bipyridin-6-onato; 12) were selectively synthesized by different synthetic routes (Tomon, Koizumi \& Tanaka, 2005). These isomers bearing 12 were determined by X-ray crystal structure analysis. Based on their $\mathrm{p} K_{\mathrm{a}}$ 's, redox potentials and IR spectra, the electron density at the ruthenium center of the distal isomer in Fig. 18 is higher than that of the proximal isomer. Such a difference is associated with the stronger trans influence of $\mathrm{CO}$ compared with the central pyridine of tpy, because the electron-withdrawing ability of $\mathrm{CO}$ induces the pyridonato structure of the resonance between ruthenium-pyridionate $\left(\mathrm{Ru}^{-b p y O}-\right)$ and -pyridonato ( $\left.\mathrm{Ru}-\mathrm{bpyO}\right)$ forms. The two-electron reductions of the distal isomer are followed by a partial $\mathrm{Ru}-\mathrm{CO}$ bond cleavage, whereas the 12-based reduction of the proximal isomer causes cyclometallation by 
an attack of the pyridonato oxygen at the carbonyl carbon. Thus, cyclometallation caused by 12-based reduction effectively suppresses the reductive cleavage of a $\mathrm{Ru}-\mathrm{CO}$ bond.
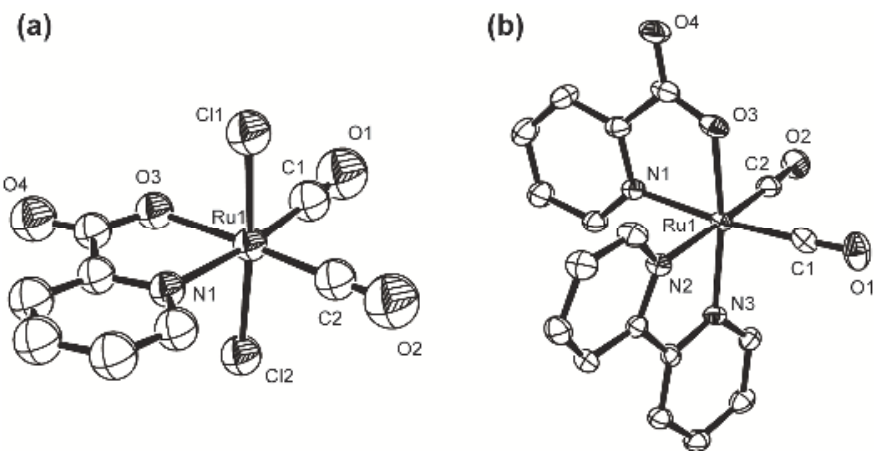

Fig. 17. Molecular structures of (a): $\left[\mathrm{Ru}(11)(\mathrm{CO})_{2} \mathrm{Cl}_{2}\right]^{-}$(isomer (i) in Fig. 16(a)), (b): $\left[\mathrm{Ru}(\mathrm{bpy})(11)(\mathrm{CO})_{2}\right]^{+}$(isomer (iv) in Fig. 16(b)).

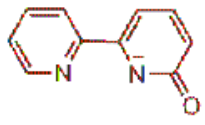

(12)
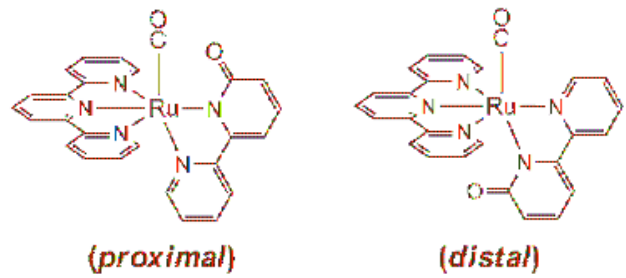

(distal)

Fig. 18. Chemical structure of 2,2'-bipyridin-6-onato (bpyO) and two geometrical isomers in $\left[\operatorname{Ru}(\text { tpy) }(12)(\mathrm{CO})]^{+}\right.$.

\subsection{Coordination modes}

It is known that not only some acido anions such as $\mathrm{NO}_{3}^{-}, \mathrm{CO}_{2} \mathrm{R}^{-}$and $\mathrm{CO}_{3}{ }^{2-}$, but also organic ligands having multi donor atoms, can coordinate to metals as monodentates, chelating bidentates, or bridging bidentate ligands. In this section, such examples are presented.

In coordination compounds, the $\mathrm{NO}_{3}^{-}$ion can be noncoordinating (counter ion), or it can coordinate in a monodentate $\left(\mathrm{NO}_{3}-\mathrm{O}\right)$ or bidentate $\left(\mathrm{NO}_{3}-\mathrm{O}, \mathrm{O}^{\prime}\right)$ fashion. The $\mathrm{N}-\mathrm{O}$ stretching vibrations, for example, are observed at 1475, 1272 and $991 \mathrm{~cm}^{-1}$ in the IR spectrum of cis$\left[\mathrm{Ru}(\mathrm{bpy})_{2}(\mathrm{CO})\left(\mathrm{NO}_{3}\right)\right] \mathrm{PF}_{6}$ (Oyama et al., 2011). It is rather difficult to differentiate between these structures by vibrational spectroscopy because the symmetry of the $\mathrm{NO}_{3}$ - ion differs very little between them ( $C_{s}$ vs. $C_{2 v}$ symmetry) (Nakamoto, 1986). However, $X$-ray data clearly indicates the monodentate coordination of the $\mathrm{NO}_{3}$ - ion. The sums of the three $\mathrm{O}-\mathrm{N}-$ $\mathrm{O}$ bond angles in the nitrato ligand are $360.0^{\circ}$, indicating that the nitrato moiety has a planar structure.

Extensive studies have been made on metal complexes of carboxylic acids. The carboxylate ion may also coordinate to a metal in a monodentate $\left(\mathrm{CO}_{2} \mathrm{R}-\mathrm{O}\right)$ or bidentate $\left(\mathrm{CO}_{2} \mathrm{R}-\mathrm{O}, \mathrm{O}^{\prime}\right)$ mode. In general, the coordination mode of the carboxylate ion is distinguishable using vibrational spectroscopy (Deacon \& Phillips, 1980). Monodentate complexes exhibit 
$\Delta v$ values $\left(v_{\mathrm{as}}\left(\mathrm{CO}_{2}^{-}\right)-v_{\mathrm{s}}\left(\mathrm{CO}_{2^{-}}\right)\right)$which are much greater than the ionic compounds, whereas chelating (bidentate) complexes exhibit $\Delta v$ values which are significantly less than the ionic values. For example, the cis- $\left[\mathrm{Ru}(\mathrm{bpy})_{2}(\mathrm{CO})\left(\mathrm{CO}_{2} \mathrm{H}\right)\right]^{+}$complex shows the large formato $\Delta v$ value of $339 \mathrm{~cm}^{-1}$ (Gibson et al., 1999), and this value is clearly greater than the ionic value $\left(\Delta v=201 \mathrm{~cm}^{-1}\right)$ (Ito \& Bernstein, 1956). X-ray structural data for this complex clearly identified the monodentate formato ligand $\left(\mathrm{CO}_{2} \mathrm{H}-\mathrm{O}\right)$ bound to an octahedral ruthenium center (Gibson et al., 1999).

As stated above, the azopyridine ligand (3) generally coordinates to a metal ion through both pyridyl and azo nitrogens (bidentate chelate fashion). However, the crystal structure of a ruthenium complex containing 3 as a monodentate ligand $\left(\left[\mathrm{Ru}(\mathrm{bpy})_{2}(3-N)(\mathrm{CO})\right]^{2+}\right)$ has been reported (Fig. 19(a)) (Oyama, Fujita \& Yui, 2008). The ligand 3 coordinates to the ruthenium center through only the pyridyl nitrogen atom. The remarkable feature in the structure of this complex concerns the azo moiety of 3 , which is directed toward the adjacent terminal carbonyl ligand. Taking into account the fact that the nitrogen atom of the azo group is located just to the side of the carbonyl carbon, the existence of the $\mathrm{CO}$ ligand could influence the orientation of the azo moiety of 3 . The redox reactions of $\left[\operatorname{Ru}(b p y)_{2}(3-\right.$ $N)(\mathrm{CO})]^{2+}$ using solution IR spectra under electrolysis conditions revealed a nucleophilic attack of the azo nitrogen atom of 3 on the carbonyl carbon (Fig. 20(a)), because of the short interatomic distance between the azo nitrogen and the carbonyl carbon atoms $(2.865 \AA)$. In contrast, the dissociation of $\mathrm{CO}$ from the two-electron reduced species easily occurs in the analogue with the bidentate $3\left(\left[\mathrm{Ru}(\operatorname{tpy})\left(3-N_{,} N^{\prime}\right)(\mathrm{CO})\right]^{2+}\right.$; Fig. $\left.19(\mathrm{~b})\right)$, because the ligand is unable to interact with CO (Fig. 20(b)).

(a)

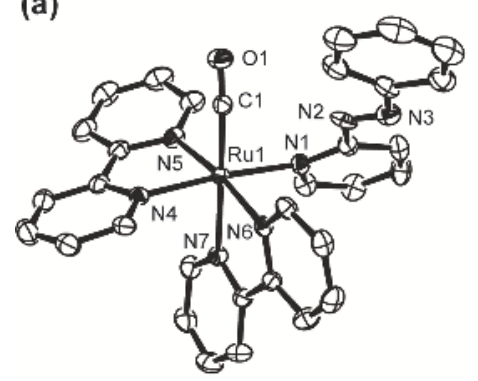

(b)

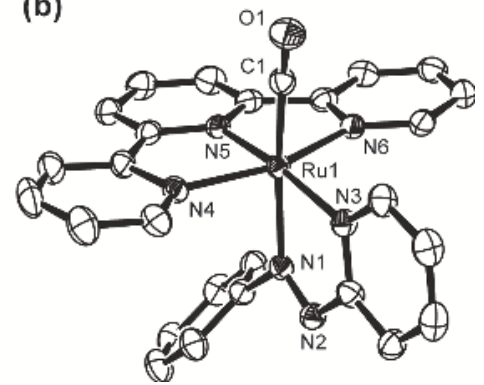

Fig. 19. Molecular structures of (a): $\left[\operatorname{Ru}(\mathrm{bpy})_{2}(3-N)(\mathrm{CO})\right]^{2+},(\mathrm{b}):\left[\operatorname{Ru}(\operatorname{tpy})\left(3-N_{,} N^{\prime}\right)(\mathrm{CO})\right]^{2+}$.

The diphenyl-2-phosphinopyridine ligand (dppy; 13) has been used to construct interesting metal complexes because it possesses both the soft $(\mathrm{P})$ and hard $(\mathrm{N})$ donor atoms (Newkome, 1993). Although both the $P$-mono and $P, N$-bidentate coordination modes have been known for mononuclear systems (Fig. 21) (Moldes et al., 1998), 13 coordinates to the ruthenium center through only the $\mathrm{P}$ atom in $\left[\mathrm{Ru}(\mathrm{bpy})(13)(\mathrm{CO}){ }_{2} \mathrm{Cl}\right]^{+}($Ooyama \& Sato, 2003). A prominent feature of the structure is that the pyridyl nitrogen atom of 13 directs toward the plane that includes two carbonyl ligands (Fig. 22(a)). The existence of carbonyl ligands may influence the orientation of the aromatic rings of 13 because relatively short distances between the noncoordinating nitrogen atom of 13 and the carbonyl carbons are observed (3.068 $\mathrm{A})$ : the analogous complex situating two 13 moieties in mutually trans positions also exhibits a similar trend as shown in Fig. 22(b) (Ooyama \& Sato, 2004). 
(a)

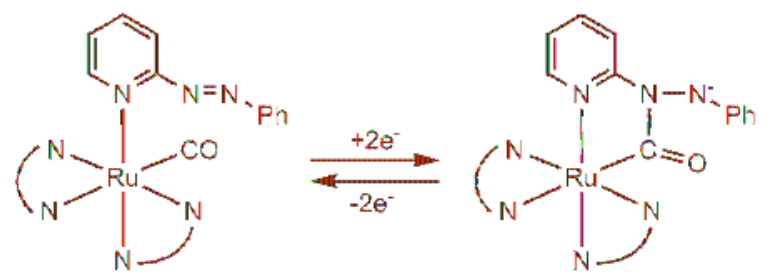

(b)

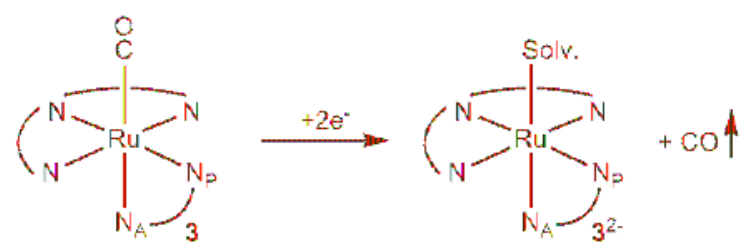

Fig. 20. The different redox behavior of the ruthenium complexes are dependent on the coordination mode of 3 . (a): $\left[\mathrm{Ru}(\mathrm{bpy})_{2}(3-\mathrm{N})(\mathrm{CO})\right]^{2+}$ (monodentate 3$)$, (b): [Ru(tpy)(3$\left.\left.N, N^{\prime}\right)(\mathrm{CO})\right]^{2+}$ (bidentate 3).
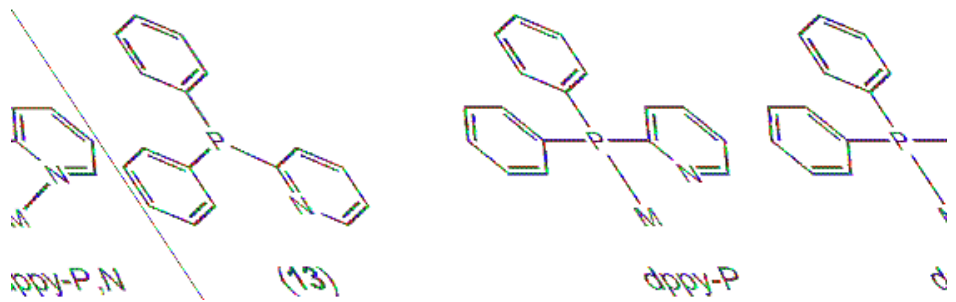

Fig. 21. Two coordination modes of diphenyl-2-phosphinopyridine (dppy).

(a)

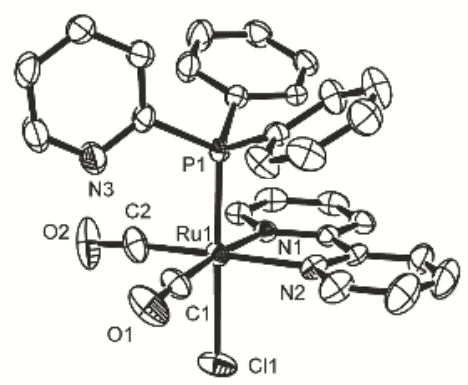

(b)

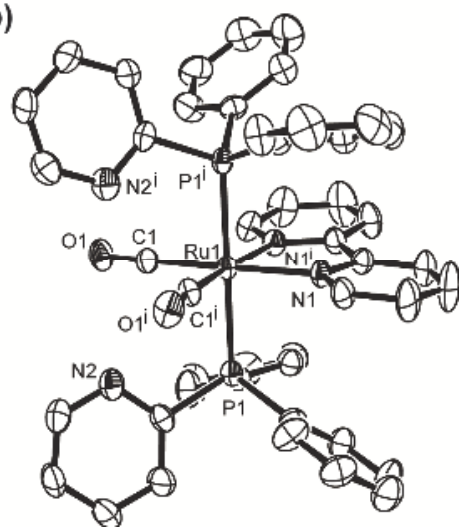

Fig. 22. Molecular structures of (a): $\left[\mathrm{Ru}(\mathrm{bpy})(13-P)(\mathrm{CO})_{2} \mathrm{Cl}\right]^{+},(\mathrm{b}):\left(\left[\mathrm{Ru}(\mathrm{bpy})(13-P)_{2}(\mathrm{CO})_{2}\right]^{2+}\right.$. 


\section{Comparison of the structures and structural parameters}

When chemists simply recognize the molecular structure of a compound, they usually pay particular attention to the points described above. However, it is also very helpful for chemists to understand how intermolecular forces (packing forces) act between molecules in crystals when they investigate the constructions of materials and medicines. In addition, various chemical and physical properties can be predicted by comparing bond parameters (e.g., bond distances, angles or torsion angles) in a compound.

\subsection{Comparison of structures}

Almost all structurally characterized coordination compounds of azopyridines have the ligand bonded to one metal center via the azoimine $(\mathrm{N}=\mathrm{N}-\mathrm{C}=\mathrm{N})$ chelate arrangement. In the case of 3 and 4, formation of a chelate complex creates the free aromatic ring (phenyl for 3 or 2-pyridyl for 4). The orientation of the pendant aromatic ring is dependent on its coordination environment: the dihedral angle between the two aromatic rings of $\left[\mathrm{Ru}(3)(\mathrm{CO})_{2} \mathrm{Cl}_{2}\right]$ is $35.29^{\circ}$ (Fig. 23(a)) whereas the dihedral angle between the two pyridyl rings in $\left[\mathrm{Ru}(4)(\mathrm{CO})_{2} \mathrm{Cl}_{2}\right]$ is $7.99^{\circ}$ (Fig. $23(\mathrm{~b})$ ), which shows planarity of the coordinated 4 (Oyama et al., 2009). The distinction observed in solid state can be explained on the basis of a possible weak interaction between the noncoordinating nitrogen atom and the adjacent carbonyl carbon in $\left[\mathrm{Ru}(4)(\mathrm{CO})_{2} \mathrm{Cl}_{2}\right]$ rather than a different bulkiness between the $\mathrm{CH}$ in phenyl ring of 3 and the $\mathrm{N}$ in pyridyl ring of 4 , because the interatomic distance between the $\mathrm{N}$ atom and the adjacent $\mathrm{C}$ atom in $\left[\mathrm{Ru}(4)(\mathrm{CO})_{2} \mathrm{Cl}_{2}\right]$ is fairly short $(2.682(3) \AA)$. This weak interaction has often been observed in ruthenium carbonyl complexes with noncoordinating pyridyl moieties (Mizukawa et al., 1999; Tomon, Koizumi \& Tanaka, 2005), which contain both a pyridyl nitrogen $(\delta-)$ and a carbonyl carbon $\left(\delta^{+}\right)$.

(a)

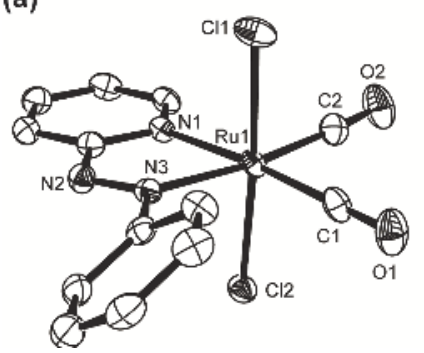

(b)

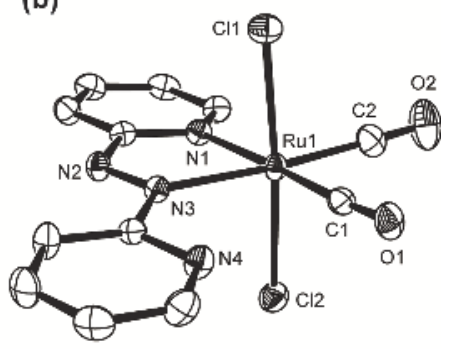

Fig. 23. Molecular structures of $\left[\mathrm{Ru}\right.$ (azopyridine) $\left.(\mathrm{CO})_{2} \mathrm{Cl}_{2}\right]$. (a): $\left[\mathrm{Ru}(3)(\mathrm{CO})_{2} \mathrm{Cl}_{2}\right]$, (b): $\left[\mathrm{Ru}(4)(\mathrm{CO})_{2} \mathrm{Cl}_{2}\right]$.

The X-ray structures of terpyridyl complexes with the dimethoxyphenyl pendant have been determined. In the metal-free ligand 14 (Fig. 24), the three pyridyl rings are approximately coplanar, whereas the dimethoxyphenyl substituent in 14 is not coplanar with the terpyridyl moiety, making an angle of $50.2^{\circ}$ with the central pyridyl ring (Storrier, Colbran \& Craig, 1998). The dihedral angle between the central pyridyl ring and the dimethoxyphenyl ring in the ruthenium complexes with 14 are in the range of 43 to $56^{\circ}$, which are close to that of metal-free ligand 14 (Oyama et al., 2009; Oyama et al., 2010). Interestingly, the $\mathrm{OCH}_{3}$ orientation of two methoxy moieties are different in two types of habits (yellow needles and red blocks) of $[\mathrm{Ru}(14)(\mathrm{bpy})(\mathrm{CO})]\left(\mathrm{PF}_{6}\right)_{2}$. As shown in Fig. 25, two $\mathrm{OCH}_{3}$ moieties point in the 
same orientation in the yellow crystal (Fig. 25(a)), whereas in the red crystal they point in opposite directions (Fig. 25(b)) (Oyama et al., 2010). The former structure is identical to the corresponding chlorido and acetonitrile complexes. On the other hand, the latter form is consistent with that observed in the metal-free 14. These differences are most likely due to different packing or intermolecular effects on the orientation of methoxy groups of 14 .<smiles>COc1ccc(OC)c(-c2cc(-c3ccccn3)nc(-c3ccccn3)c2)c1</smiles>

(a)<smiles>COc1ccc(OC)c(-c2cc(-c3ccccn3)nc(-c3ccccn3)c2)c1</smiles>

(b)

Fig. 24. Chemical structures of 14. (a): same orientation, (b): opposite orientation, regarding two methoxy groups.
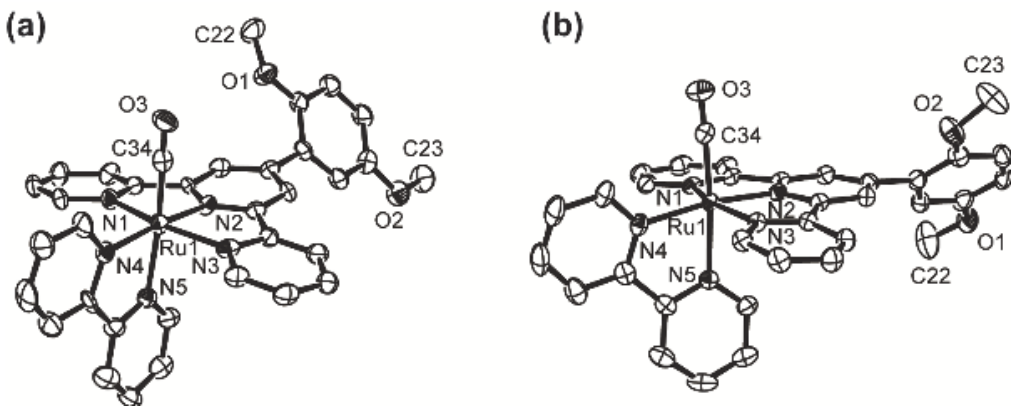

Fig. 25. Molecular structures of $[\operatorname{Ru}(14)($ bpy) $(\mathrm{CO})] 2+$. (a): the yellow crystal, (b): the red crystal.

\subsection{Comparison of structural parameters}

Physical data of terminal carbonyl groups are generally useful indicators for electronic states around metal centers in metal complexes. In particular, bond distances and vibrational spectra are considered important (Cotton et al., 1999). In order to distinguish the electron states in the ruthenium mono carbonyl complexes with polypyridyl ligands, the stretching force constants of the CO group using IR spectral data were calculated in addition to bond distances and stretching frequencies of the $\{\mathrm{Ru}-\mathrm{CO}\}^{2+}$ moiety (Oyama et al., 2009). Although obvious characteristics about the bond distances ( $\mathrm{Ru}-\mathrm{C}$ and $\mathrm{C}-\mathrm{O})$ are not shown in the complexes, the force constant $(k)$ and the stretching frequencies of the $\mathrm{CO}$ groups can clearly be divided into two groups (Table 1 ): the $k$ values of the azocontaining complexes are higher ca. $0.4-1.1 \mathrm{~N} \mathrm{~cm}^{-1}$ than of the values for the complexes without azopyridines. It is presumed that the electron density of the ruthenium center 
considerably decreases when an azo group (which has greater $\pi$-acidity) coordinates to the ruthenium atom, because the decrease of the $k$ value caused by ligand-based oneelectron reduction corresponds to $0.56 \mathrm{~N} \mathrm{~cm}^{-1}$ in $\left[\mathrm{Ru}(\mathrm{bpy})_{2}(\mathrm{CO}) \text { (quinoline) }\right]^{2+}$ (Wada et al., 2004). Thus, it can be concluded that complex formation with azopyridyl ligands induces relatively high $k$ values. This observation can be ascribed to the decrease of the $\pi$ backdonation from the ruthenium center to the $\mathrm{CO}$ group. As a result, this suggests that the azopyridyl ligands serve as prominent electron reservoirs compared with other polypyridyl ligands such as bpy.

\begin{tabular}{|c|c|c|c|c|}
\hline polypyridines* & $d(\mathrm{Ru}-\mathrm{C})$ & $d(\mathrm{C}-\mathrm{O})$ & $\mathrm{vCO}$ & $k$ \\
\hline $3 / 3$ & $1.897(5)$ & $1.136(6)$ & 2031 & 16.67 \\
\hline 4/bpy & $1.889(3)$ & $1.116(4)$ & 2002 & 16.20 \\
\hline 3/bpy & $1.891(2)$ & $1.122(3)$ & 2001 & 16.18 \\
\hline $4,4^{\prime}-\mathrm{Me}_{2}$ bpy $/ 5,6^{\prime}-\mathrm{Me}_{2}$ phen & $1.867(5)$ & $1.112(7)$ & 1978 & 15.81 \\
\hline $\mathrm{dpk} / 4,7^{\prime}-\mathrm{Me}_{2}$ phen & $1.820(11)$ & $1.146(13)$ & 1976 & 15.80 \\
\hline 10/bpy & $1.867(5)$ & $1.145(6)$ & 1975 & 15.76 \\
\hline $\mathrm{dpa} / 5,5^{\prime}-\mathrm{Me}_{2} \mathrm{bpy}$ & $1.917(4)$ & $1.026(6)$ & 1972 & 15.72 \\
\hline bpy/dpk & $1.880(5)$ & $1.119(7)$ & 1970 & 15.68 \\
\hline $4,4^{\prime}-\mathrm{Me}_{2}$ bpy $/ 4,7^{\prime}-\mathrm{Me}_{2}$ phen & $1.95(2)$ & $1.05(2)$ & 1967 & 15.64 \\
\hline bpy/dpa & $1.883(16)$ & $1.08(2)$ & 1967 & 15.64 \\
\hline bpy/phen & $1.857(4)$ & $1.126(6)$ & 1966 & 15.62 \\
\hline bpy/bpy & $1.861(29)$ & $1.122(32)$ & 1966 & 15.62 \\
\hline $\mathrm{biq} / \mathrm{biq}$ & $1.91(2)$ & $1.01(2)$ & 1964 & 15.59 \\
\hline
\end{tabular}

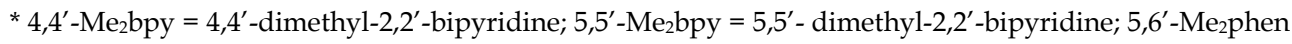
= 5,6'-dimethyl-1,10-phenanthroline; 4,7'-Merphen = 4,7'- dimethyl-1,10-phenanthroline; $\mathrm{dpk}=\mathrm{di}(2-$ pyridyl)ketone; dpa = di(2-pyridyl)amine; phen = 1,10-phenanthroline; biq = 2,2'-biquinoline.

Table 1. Bond distances $(d: \AA)$, stretching frequencies $\left(v: \mathrm{cm}^{-1}\right)$ and force constant $\left(k: \mathrm{N} \mathrm{cm}^{-1}\right)$ of the $\mathrm{CO}$ groups in cis-[Ru(polypyridine $\left.)_{2}(\mathrm{CO}) \mathrm{Cl}\right]^{+}$.

The N-N bond distance in an azo moiety is an excellent indicator of the charge on an azo group (Kaim, 2001). The values for unreduced azo N-N bonds are 1.22-1.31 $\AA$ in metal complexes (1.23-1.26 $\AA$ for metal-free ligands). The one-electron reduced (anion radical) ligands have a bond distances of 1.31-1.41 $\AA$, whereas the two-electron reduced (hydrazido) forms have single bonds with 1.41-1.50 ̊ distances (Fig. 26) (Sarkar et al., 2008). As shown in Table 2, the azo N-N bond distance of $\left[\mathrm{Ru}(\mathrm{bpy})_{2}(\mathrm{CO})(3-\mathrm{N})\right]^{2+}$ is dramatically shorter than those of other complexes: the distance $(1.188(4) \AA)$ is shorter than that of a typical $N=\mathrm{N}$ double bond (1.23 $\AA$ ) (Oyama, Fujita \& Yui, 2008).

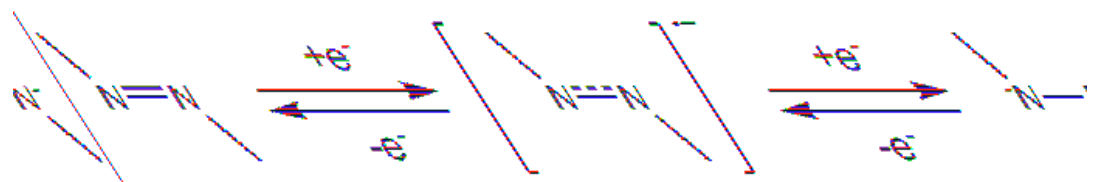

Fig. 26. Three oxidation states of an azo moiety. 


\begin{tabular}{cccc}
\hline compound & $d(\mathrm{~N}-\mathrm{N})$ & $d\left(\mathrm{M}-\mathrm{N}_{\mathrm{azo}}\right)$ & $d\left(\mathrm{M}-\mathrm{N}_{\mathrm{py}}\right)$ \\
\hline$\left[\mathrm{Ru}(3)(\mathrm{CO})_{2} \mathrm{Cl}_{2}\right]$ & $1.264(3)$ & $2.119(2)$ & $2.099(2)$ \\
{$\left[\mathrm{Ru}(4)(\mathrm{CO})_{2} \mathrm{Cl}_{2}\right]$} & $1.265(3)$ & $2.107(2)$ & $2.108(2)$ \\
{$\left[\mathrm{Ru}(3)(\mathrm{bpy})(\mathrm{CO}) \mathrm{Cl}_{2}\right] \mathrm{PF}_{6}$} & $1.287(3)$ & $2.015(2)$ & $2.095(2)$ \\
{$\left[\mathrm{Ru}(4)(\mathrm{bpy})(\mathrm{CO}) \mathrm{Cl}_{\mathrm{PF}_{6}}\right.$} & $1.291(4)$ & $1.998(2)$ & $2.114(2)$ \\
{$[\mathrm{Ru}(3)(\mathrm{tpy})(\mathrm{CO})]\left(\mathrm{ClO}_{4}\right)_{2}$} & $1.265(5)$ & $2.099(3)$ & $2.071(3)$ \\
{$[\mathrm{Ru}(4)(\mathrm{tpy}) \mathrm{Cl}] \mathrm{PF}_{6}$} & $1.299(3)$ & $1.964(2)$ & $2.054(2)$ \\
{$\left[\mathrm{Ru}(3-\mathrm{KN})\left(\mathrm{bpy}_{2}(\mathrm{CO})\right]\left(\mathrm{ClO}_{4}\right)_{2}\right.$} & $1.188(4)$ & & \\
$\left(3 \mathrm{H}^{+}\right) \mathrm{BF}_{4}$ & $1.248(4)$ & & \\
$\left(3 \mathrm{H}^{+}\right) \mathrm{ClO}_{4}$ & $1.258(5)$ & & \\
4 & $1.246(2)$ & & \\
\hline
\end{tabular}

Table 2. Bond distances $(\AA)$ in the complexes of mono-azopyridines and metal-free ligands.

In the case of bis-azopyridyl complexes, bivalent azopyridine properties are observed by the different azo N-N bond distances. For example, the structure of the monoradical $\left[\mathrm{Ru}(4)\left(4^{\bullet-}\right.\right.$ )$\left.(\mathrm{CO})\left(\mathrm{PPh}_{3}\right)\right]^{+}$has been determined (Shivakumar et al., 2000). The most remarkable feature of the structure is the difference in the two N-N bond distances: one is 1.284(6) $\AA$, the other $\mathrm{N}-\mathrm{N}$ bond is 1.336(6) $\AA$. Accordingly, both unreduced and one-electron reduced (anion radical) types are present within the same molecule, which represents a model case of ground-state radical localization in one of the two ligands. The stabilization of radical on one ligand might be supported by the trans ligand. A similar example is also reported in $\left[\mathrm{Ru}\left(7^{2-}\right)_{2}\right]$ (Samanta et al., 2008). The $\left[\mathrm{Ru}(7)_{2}\right]$ molecule has longer $\mathrm{N}-\mathrm{N}$ bond distances (1.324(7) and 1.327(6) $\AA$ ), clearly suggesting the radical dianion form of the ligand (one charge from the deprotonation and another charge from the one-electron reduction centered on the azo group). This diamagnetic molecule may thus be viewed as a singlet diradical species. In this situation, the electrons from a $\mathrm{d}^{4}$ configuration at the metal couple with the singly occupied ligand molecular orbitals to create a spin-paired entity. This situation has been confirmed by DFT (density functional theory) calculations.

\section{Conclusion}

Single crystal X-ray diffraction studies provide a valuable probe to visualize molecules. Although some problems such as disorder and twining exist in measurements and analyses, it still represents the most important analytical method for coordination chemists. The author believes that advances in this technology will lead to an increase in the use of single crystal X-ray diffraction, including the X-ray snapshot technique which enables the capture of frame-by-frame movies of chemical reactions as they proceed in situ, now ubiquitous in NMR (Inokuma, Kawano \& Fujita, 2011).

\section{Acknowledgment}

The endeavors of past and present co-workers from my research group in obtaining the results presented in this chapter are gratefully acknowledged, their names appear in the reference list. The Institute for Molecular Science, Bruker AXS Japan and Rigaku Corporation are gratefully acknowledged for performing X-ray measurements of some complexes. Finally, I thank Mr. Takashi Yamanaka for his contribution in writing this chapter. 


\section{References}

Abe, T.; Suzuki, T. \& Shinozaki, K. (2010). Luminescence Change by the Solvent of Crystallization, Solvent Reorganization, and Vapochromism of Neutral Dicyanoruthenium(II) Complex in the Solid State. Inorganic Chemistry, Vol.49, No.4, pp. $4794-4800$

Bao, T.; Krause, K. \& Krause, R. A. (1988). Hydroxide-assisted Stereospecific Isomerization of a trans-Dichlorobischelate of Ruthenium(II). Inorganic Chemistry, Vol.27, No.4, pp. 759-761

Cheng, J. Y. K.; Cheung, K.-K. \& Che, C.-M. (1997). Synthesis, Characterization and Photophysical Properties of $\left[\mathrm{OsO}_{2}(\mathrm{mes})_{2}(\mathrm{NC}) \mathrm{Ru}(\mathrm{bpy})_{2}(\mathrm{CN})\right]$. Chemical Communications, No.5, pp. 501-502

Chow, C.-F.; Lam, M. H. W.; Sui, H. \& Wong, W.-Y. (2005). Design and Synthesis of Heterobimetallic Donor-Acceptor Chemodosimetric Ensembles for the Detection of Sulfhydryl-containing Amino Acids and Peptides. Dalton Transactions, No.3, pp. 475-484

Chowdhury, A. D.; Das, A.; Irshad, K.; Mobin, S. M. \& Lahiri, G. K. (2011). Isomeric Complexes of $\left[\mathrm{Ru}^{\mathrm{II}}(\operatorname{trpy})(\mathrm{L}) \mathrm{Cl}\right]\left(\operatorname{trpy}=2,2^{\prime}: 6^{\prime}, 2^{\prime \prime}\right.$-Terpyridine and $\mathrm{HL}=$ Quinaldic Acid): Preference of Isomeric Structural Form in Catalytic Chemoselective Epoxidation Process. Inorganic Chemistry, Vol.50, No.5, pp. 1775-1785

Clear, J. M.; Kelly, J. M.; O'Connell, C. M.; Vos, J. G.; Cardin, C. J.; Costa, S. R. \& Edwards, A. J. (1980). Isolation, Structure, Chemistry, and Photochemistry of cis-Bis(2,2'bipyridyl)carbonylchlororuthenium(II) Perchlorate. Journal of Chemical Society, Chemical Communications, No.16, pp. 750-751

Corral, E.; Hotze, A. C. G.; Tooke, D. M.; Spek, A. L. \& Reedijk, J. (2006). Ruthenium Polypyridyl Complexes Containing the Bischelating Ligand 2,2'-Azobispyridine. Synthesis, Characterization and Crystal Structures. Inorganica Chimica Acta, Vol.359, No.3, pp. 830-838

Cotton, F. A.; Wilkinson, G.; Murillo, C. A. \& Bochmann, M. (1999). Advanced Inorganic Chemistry, 6th Ed., Wiley-Interscience, ISBN 0-471-19957-5, New York, USA

Dakkach, M.; López, M. I.; Romero, I.; Rodríguez, M.; Atlamsani, A.; Parella, T.; Fontrodona, X. \& Llobet, A. (2010). New Ru(II) Complexes with Anionic and Neutral N-Donor Ligands as Epoxidation Catalysts: An Evaluation of Geometrical and Electronic Effects. Inorganic Chemistry, Vol. 49, No.15, pp. 7072-7079

Das, C.; Saha, A.; Hung, C.-H.; Lee, G.-H.; Peng, S.-M. \& Goswami, S. (2003). Ruthenium Complexes of 2-[(4-(Arylamino)phenyl)azo]pyridine Formed via Regioselective Phenyl Ring Amination of Coordinated 2-(Phenylazo)pyridine: Isolation of Products, X-ray Structure, and Redox and Optical Properties. Inorganic Chemistry, Vol.42, No.1, pp. 198-204

Das, D.; Mondal, T. K.; Mobin, S. M. \& Lahiri, G. K. (2009). Sensitive Valence Structures of $\left[(\text { pap })_{2} \operatorname{Ru}(\mathrm{Q})\right]^{n}(n=+2,+1,0,-1,-2)$ with Two Different Redox Noninnocent Ligands, $\mathrm{Q}=3,5$-Di-tert-butyl- $\mathrm{N}$-aryl-1,2-benzoquinonemonoimine and pap $=2$ Phenylazopyridine. Inorganic Chemistry, Vol.48, No.20, pp. 9800-9810

Deacon, G. B. \& Phillips, R. J. (1980). Relationships between the Carbon-Oxygen Stretching Frequencies of Carboxylato Complexes and the Type of Carboxylate Coordination. Coordination Chemistry Reviews, Vol.33, No.3, pp. 227-250 
Gibson, D. H.; Ding, Y.; Miller, R. L.; Sleadd, B. A.; Mashuta, M. S. \& Richardson, J. F. (1999). Synthesis and Characterization of Ruthenium, Rhenium and Titanium Formate, Acetate and Trifluoroacetate Complexes. Correlation of IR Spectral Properties and Bonding Types. Polyhedron, Vol.18, Nos.8-9, pp.1189-1200

Goswami, S.; Chakravarty, A. R. \& Chakravorty, A. (1981). Chemistry of Ruthenium. 2. Synthesis, Structure, and Redox Properties of 2-(Arylazo)pyridine Complexes. Inorganic Chemistry, Vol.20, No.7, pp. 2246-2250

Hotze, A. C. G.; Velders, A. H.; Ugozzoli, F.; Biagini-Cingi, M.; Manotti-Lanfredi, A. M.; Haasnoot, J. G. \& Reedijk, J. (2000). Synthesis, Characterization, and Crystal Structure of $\alpha-\left[\mathrm{Ru}(\text { azpy })_{2}\left(\mathrm{NO}_{3}\right)_{2}\right]$ (azpy $=2$-(Phenylazo)pyridine) and the Products of Its Reactions with Guanine Derivatives. Inorganic Chemistry, Vol.39, No.17, pp. 3838-3844

Hotze, A. C. G.; Van der Geer, E. P. L.; Kooijman, H.; Spek, A. L.; Haasnoot, J. G. \& Reedijk, J. (2005). Characterization by NMR Spectroscopy, X-ray Analysis and Cytotoxic Activity of the Ruthenium(II) Compounds $\left[\mathrm{RuL}_{3}\right]\left(\mathrm{PF}_{6}\right)_{2}(\mathrm{~L}=$ 2-Phenylazopyridine or $o$-Tolylazopyridine) and $\left[\mathrm{RuL}_{2}{ }_{2} \mathrm{~L}^{\prime \prime}\right]\left(\mathrm{PF}_{6}\right)_{2}\left(\mathrm{~L}^{\prime}, \mathrm{L}^{\prime \prime}=\right.$ 2-Phenylazopyridine, $2,2^{\prime}-$ Bipyridine). European Journal of Inorganic Chemistry, No.13, pp. 2648-2657

Inokuma, Y.; Kawano, M. \& Fujita, M. (2011). Crystalline Molecular Flasks. Nature Chemistry, Vol.3, No.5, pp. 349-358

Ito, K. \& Bernsrein,H. J. (1956). The Vibrational Spectra of the Formate, Acetate, and Oxalate Ions. Canadian Journal of Chemistry, Vol.34, No.2, pp. 170-178

Kaim, W. (2001). Complexes with 2,2'-Azobispyridine and Related 'S-frame' Bridging Ligands Containing the Azo Function. Coordination Chemistry Reviews, Vols.219-221 (October), pp.463-488

Kepert, C. M.; Deacon, G. B.; Sahely, N.; Spiccia, L.; Fallon, G. D.; Skelton, B. W. \& White, A. H. (2004). Synthesis of Heteroleptic Bis(diimine)carbonylchlororuthenium(II) Complexes from Photodecarbonylated Precursors. Inorganic Chemistry, Vol.43, No.9, pp. 2818-2827

Mondal, B.; Walawalkar, M. G. \& Lahili, G. K. (2000). Ruthenium Terpyridine Complexes Incorporating Azo-imine Based Ancillary Ligands. Synthesis, Crystal Structure, Spectroelectrochemical Properties and Solution Reactivities. Journal of Chemical Society, Dalton Transactions, No.22, pp. 4209-4217

Mondal, B.; Paul, H.; Puranik, V. G. \& Lahiri, G. K. (2001). Ruthenium Mononitro and Mononitroso Terpyridine Complexes Incorporating Azoimine Based Ancillary Ligands. Synthesis, Crystal Structure, Spectroelectrochemical Properties and Kinetic Aspects. Journal of Chemical Society, Dalton Transactions, No.4, pp. 481-487

Krause, R. A. \& Krause, K. (1980). Chemistry of Bipyridyl-like Ligands. Isomeric Complexes of Ruthenium(II) with 2-(Phenylazo)pyridine. Inorganic Chemistry, Vol.19, No.9, pp. 2600-2603

Krause, R. A. \& Krause, K. (1982). Chemistry of Bipyridyl-like Ligands. 2. Mixed Complexes of Ruthenium(II) with 2-(Phenylazo)pyridine: A New $\pi$-Bonding Probe. Inorganic Chemistry, Vol.21, No.5, pp. 1714-1720

Mizukawa, T.; Tsuge, K.; Nakajima, H. \& Tanaka, K. (1999). Selective Production of Acetone in the Electrochemical Reduction of $\mathrm{CO}_{2}$ Catalyzed by a Ru-Naphthyridine Complex. Angewandte Chemie International Edition, Vol.38, No.3, pp. 362-363 
Moldes, I.; Encarnación, E.; Ros, J.; Alvarez-Larena, Á. \& Piniella, J. F. (1998). Rutheium(II) Complexes Containing Both Arene and Functionalized Phosphines. Synthesis and Catalytic Activity for the Hydrogenation of Styrene and Phenylacetylene. Journal of Organometallic Chemistry, Vol.566, Nos.1-2, pp. 165-174

Nakamoto, K. (1986). Infrared and Raman Spectra of Inorganic and Coordination Compounds, 4th Ed., Wiley-Interscience, ISBN 0-471-01066-9, New York, USA

Newkome, G. R. (1993). Pyridylphosphines. Chemical Reviews, Vol.93, No.6, pp. 2067-2089

Ooyama, D.; Kobayashi, T.; Shiren, K. \& Tanaka, K. (2003). Regulation of Electron Donating Ability to Metal Center: Isolation and Characterization of Ruthenium Carbonyl Complexes with $\mathrm{N}, \mathrm{N}$ - and/or N,O-donor Polypyridyl Ligands. Journal of Organometallic Chemistry, Vol.665, Nos.1-2, pp. 107-113

Ooyama, D. \& Sato, M. (2003). Crystal Structure of $\left(2,2^{\prime}\right.$-Bipyridine- $\left.N, N^{\prime}\right)$ (diphenyl-2phosphinopyridine- $P$ )chloro(dicarbonyl)ruthenium(II) Hexafluorophosphate. Analytical Sciences, Vol.19, No.4, pp. x39-x40

Ooyama, D. \& Sato, M. (2004). A Synthetic Precursor for Hetero-binuclear Metal Complexes, $\left[\mathrm{Ru}(\mathrm{bpy})(\mathrm{dppy})_{2}(\mathrm{CO})_{2}\right]\left(\mathrm{PF}_{6}\right)_{2} \quad\left(\right.$ bpy $=2,2^{\prime}$-Bipyridine, dppy $=2-$ (Diphenylphosphino)pyridine). Applied Organometallic Chemistry, Vol.18, No.8, pp. 380-381

Ooyama, D. \& Asaha, S. (2005). Crystal Structure of a Chlororuthenium(II) Complex with Polypyridyl Ligands, 2-Pyridyl-2-azopyridine and 2,2':6',2"'-Terpyridine. Analytical Sciences, Vol. 21, No.3, pp. x43-x44

Oyama, D.; Fujita, R. \& Yui, S. (2008). Mono- and Bidentate Azopyridyl Ruthenium(II) Complexes: Their Crystal Structures and Different Redox Behavior. Inorganic Chemistry Communications, Vol.11, No.3, pp. 310-313

Oyama, D.; Asuma, A. \& Takase, T. (2008). Stereospecific Formation of Polypyridylruthenium(II) Complexes Incorporating an Asymmetrical Bidentate Ligand: Influence of Coligands. Inorganic Chemistry Communications, Vol. 11, No.9, pp. 1097-1099

Oyama, D.; Asuma, A.; Hamada, T. \& Takase, T. (2009). Novel [Ru(polypyridine) $\left.(\mathrm{CO}){ }_{2} \mathrm{Cl}_{2}\right]$ and $\left[\mathrm{Ru}(\text { polypyridine })_{2}(\mathrm{CO}) \mathrm{Cl}\right]^{+}$-type Complexes: Characterizing the Effects of Introducing Azopyridyl Ligands by Electrochemical, Spectroscopic and Crystallographic Measurements. Inorganica Chimica Acta, Vol.362, No.8, pp. 25812588

Oyama, D.; Kido, M.; Orita, A. \& Takase, T. (2009). (2,2'-Bipyridine- $\left.\kappa^{2} N, N^{\prime}\right)$ chlorido[4'-(2,5dimethoxyphenyl)-2,2': $6^{\prime}, 2^{\prime \prime}$-terpyridine- $\left.\kappa^{3} N, N^{\prime}, N^{\prime \prime}\right]$ ruthenium(II) Hexafluoridophosphate Acetonitrile Monosolvate. Acta Crystallographica Section E, Vol.E65, No.9, pp. m1117-m1118

Oyama, D.; Kido, M.; Orita, A \& Takase, T. (2010). Synthesis, Structure, Redox Property and Ligand Replacement Reaction of Ruthenium(II) Complexes Containing a Terpyridyl Ligand with a Redox Active Moiety. Polyhedron, Vol.29, No.4, pp. 13371343

Oyama, D.; Takatsuki, Y. \& Fujita, R. (2010). Azopyridylruthenium(II) Complexes Containing Ru-C Bonds: Synthesis, Characterization and Reactivity. Trends in Inorganic Chemistry, Vol.12, pp. 31-40 
Oyama, D.; Hamada, T. \& Takase, T. (2011). Stereospecific Synthesis and Redox Properties of Ruthenium(II) Carbonyl Complexes Bearing a Redox-active 1,8-Naphthyridine Unit. Journal of Organometallic Chemistry, Vol.696, No.10, pp.2263-2268

Oyama, D.; Yuzuriya, K. \& Takase, T. (2011). Aqua[2-(2-pyridyl)-1,8-naphthyridine$\left.\kappa^{2} N^{1}, N^{2}\right]\left(2,2^{\prime}: 6^{\prime}, 2^{\prime \prime}\right.$-terpyridine- $\left.\kappa^{3} N, N^{\prime}, N^{\prime}\right)$ ruthenium(II)

Bis(hexafluoridophosphate) Acetone Sesquisolvate. Acta Crystallographica Section E, Vol.E67, No.6, pp. m737-m738

Oyama, D.; Suzuki, K.; Yamanaka, T. \& Takase, T. (2011). One-pot Synthesis of cis-Bis(2,2'bipyridine)carbonylruthenium(II) Complexes from the Carbonato Precursor: X-ray Crystal Structures and Evaluation of Electron-Transfer Processes of the Series Complexes. Submitted for publication

Reedijk, J. (1996). Improved Understanding in Platinium Antitumour Chemistry. Chemical Communications, No.7, pp. 801-806

Rosenberg, B.; Van Camp, L.; Trosko, J. E. \& Mansour, V. H. (1969). Platinum Compounds: a New Class of Potent Antitumour Agents. Nature, Vol.222, No.5191, pp. 385-386

Samanta, R.; Mondal, B.; Munshi, P. \& Lahiri, G. K. (2001). Mononuclear and Dinuclear Ruthenium(II)/(III) Salicylates Incorporating Azoimine Functionalities as Ancillary Ligands. Synthesis, Spectroscopic and Electron-Transfer Properties. Journal of Chemical Society, Dalton Transactions, No.12, pp. 1827-1833

Samanta, S.; Singh, P.; Fiedler, J.; Záliš, S.; Kaim, W. \& Goswami, S. (2008). Signal Diradical Complexes of Ruthenium and Osmium: Geometrical and Electronic Structures and Their Unexpected Changes on Oxidation. Inorganic Chemistry, Vol.47, No.5, pp. 1625-1633

Sarkar, B.; Patra, S.; Fiedler, J.; Sunoj, R. B.; Janardanan, D.; Lahiri, G. K. \& Kaim, W. (2008). Mixed-Valent Metals Bridged by a Radical Ligand: Fact or Fiction Based on Structure-Oxidation State Correlations. Journal of the American Chemical Society, Vol.130, No.11, pp. 3532-3542

Seal, A. \& Ray, S. (1984). Structures of Two Isomers of Dichlorobis(2phenylazopyridine)ruthenium(II), $\left[\mathrm{RuCl}_{2}\left(\mathrm{C}_{11} \mathrm{H}_{9} \mathrm{~N}_{3}\right)_{2}\right]$. Acta Crystallographica Section C, Vol.C40, No.6, pp. 929-932

Shivakumar, M.; Pramanik, K.; Bhattacharyya, I. \& Chakravorty, A. (2000). Chemistry of Metal-Bound Anion Radicals. A Family of Mono- and Bis(azopyridine) Chelates of Bivalent Ruthenium. Inorganic Chemistry, Vol.39, No.19, pp. 4332-4338

Storrier, G. D.; Colbran, S. B. \& Craig, D. C. (1998). Transition-metal Complexes of Terpyridine Ligands with Hydroquinone or Quinone Substituents. Journal of Chemical Society, Dalton Transactions, No.8, pp. 1351-1363

Tomon, T.; Koizumi, T. \& Tanaka, K. (2005). Stabilization and Destabilization of the Ru-CO Bond During the 2,2'-Bipyridin-6-onato (bpyO)-Localized Redox Reaction of $[\mathrm{Ru}($ terpy $)(\mathrm{bpyO})(\mathrm{CO})]\left(\mathrm{PF}_{6}\right)$. European Journal of Inorganic Chemistry, No.2, pp. 285293

Tomon, T.; Koizumi, T. \& Tanaka, K. (2005). Electrochemical Hydrogenation of $\left[\mathrm{Ru}(\mathrm{bpy})_{2}(\text { napy- } \kappa N)(\mathrm{CO})\right]^{2+}$ : Inhibition of Reductive Ru-CO Bond Cleavage by a Ruthenacycle. Angewandte Chemie International Edition, Vol.44, No.15, pp. 2229-2232

Tseng, H.-W.; Zong, R.; Muckerman, J. T. \& Thummel, R. (2008). Mononuclear Ruthenium(II) Complexes That Catalyze Water Oxidation. Inorganic Chemistry, Vol.47, No.24, pp. 11763-11773 
Velders, A. H.; Kooijman, H.; Spek, A. L.; Haasnoot, J. G.; de Vos, D. \& Reedijk, J. (2000). Strong Differences in the in Vitro Cytotoxicity of Three Isomeric Dichlorobis(2phenylazopyridine)ruthenium(II) Complexes. Inorganic Chemistry, Vol.39, No.14, pp. 2966-2967

Velders, A. H.; Van der Schilden, K.; Hotze, A. C. G.; Reedijk, J.; Kooijman, H. \& Spek, A. L. (2004). Dichlorobis(2-phenylazopyridine)ruthenium(II) Complexes: Characterisation, Spectroscopic and Structural Properties of Four Isomers. Dalton Transactions, No.3, pp. 448-455

Wada, T.; Fujihara, T.; Tomori, M.; Ooyama, D. \& Tanaka, K. (2004). Strong Interaction between Carbonyl and Dioxolene Ligands Caused by Charge Distribution of Ruthenium-Dioxolene Frameworks of Mono- and Dicarbonylruthenium Complexes. Bulletin of the Chemical Society of Japan, Vol.77, No.4, pp. 741-749

Zhou, Y.; Xiao, H.-P.; Kang, L.-C.; Zuo, J.-L.; Li, C.-H. \& You, X.-Z. (2009). Synthesis and Characterization of Neutral Iron(II) and Ruthenium(II) Complexes with the Isocyanotriphenylborate Ligand. Dalton Transactions, No.46, pp. 10256-10262 


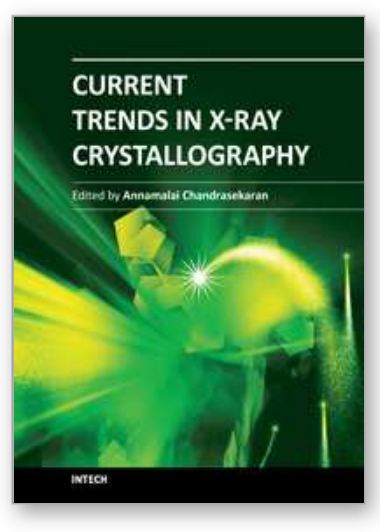

\author{
Current Trends in X-Ray Crystallography \\ Edited by Dr. Annamalai Chandrasekaran
}

ISBN 978-953-307-754-3

Hard cover, 436 pages

Publisher InTech

Published online 16, December, 2011

Published in print edition December, 2011

This book on X-ray Crystallography is a compilation of current trends in the use of X-ray crystallography and related structural determination methods in various fields. The methods covered here include single crystal small-molecule X-ray crystallography, macromolecular (protein) single crystal X-ray crystallography, and scattering and spectroscopic complimentary methods. The fields range from simple organic compounds, metal complexes to proteins, and also cover the meta-analyses of the database for weak interactions.

\title{
How to reference
}

In order to correctly reference this scholarly work, feel free to copy and paste the following:

Dai Oyama (2011). Role of X-Ray Crystallography in Structural Studies of Pyridyl-Ruthenium Complexes, Current Trends in X-Ray Crystallography, Dr. Annamalai Chandrasekaran (Ed.), ISBN: 978-953-307-754-3, InTech, Available from: http://www.intechopen.com/books/current-trends-in-x-ray-crystallography/role-of-x-raycrystallography-in-structural-studies-of-pyridyl-ruthenium-complexes

\section{INTECH}

open science | open minds

\section{InTech Europe}

University Campus STeP Ri

Slavka Krautzeka 83/A

51000 Rijeka, Croatia

Phone: +385 (51) 770447

Fax: +385 (51) 686166

www.intechopen.com

\section{InTech China}

Unit 405, Office Block, Hotel Equatorial Shanghai

No.65, Yan An Road (West), Shanghai, 200040, China 中国上海市延安西路65号上海国际贵都大饭店办公楼 405 单元

Phone: +86-21-62489820

Fax: $+86-21-62489821$ 
(C) 2011 The Author(s). Licensee IntechOpen. This is an open access article distributed under the terms of the Creative Commons Attribution 3.0 License, which permits unrestricted use, distribution, and reproduction in any medium, provided the original work is properly cited. 